\section{POČINITELJI SEKSUALNOG NASILJA S INTELEKTUALNIM TEŠKOĆAMA}

Pregledni članak

Primljeno: srpanj, 2015.

Prihvaćeno: listopad, 2016.

UDK 343.541-056.36

DOI 10.3935/ljsr.v23i2.96

Marko Buljevac

Marija Luketić ${ }^{2}$

Zdravka Leutar ${ }^{3}$

Sveučilište u Zagrebu

Pravni fakultet

Studijski centar socijalnog rada

Svrha ovog rada je predstaviti i problematizirati spoznaje o počiniteljima seksualnog nasilja s intelektualnim teškoćama, budući da su ove osobe neprepoznata i marginalizirana skupina počinitelja koja ne dobiva odgovarajući tretman u suvremenom društvu. $\mathrm{Na}$ samom početku problematizira se seksualnost osoba s intelektualnim teškoćama kao temelje počinjenja seksualnog nasilja, što se povezuje s položajem ovih osoba u društvu i ostvarivanjem nekih njihovih prava. Spoznaje o obilježjima ličnosti počinitelja seksualnog nasilja s intelektualnim teškoćama povezuju se s pravom na seksualnost i pristup informacijama o interpersonalnim odnosima, što se dovodi u vezu sa saznanjima i specifičnostima o oblicima i žrtvama seksualnog nasilja počinjenog od muškaraca s intelektualnim teškoćama. Na kraju rada objašnjeni su tretmani s počiniteljima seksualnog nasilja s intelektualnim teškoćama koji se primjenjuju u državama zapadne i sjeverne Europe te SAD-a, ali $i$ prepoznata problematika vezana uz recidivizam ove vrste nasilja. Kroz zaključna razmatranja autori sumiraju

\footnotetext{
Doc.dr.sc. Marko Buljevac, socijalni radnik, e-mail:mbuljevac@pravo.hr

2 Marija Luketić, magistra socijalnog rada, e-mail: luketicmarija.scsr@gmail. com

3 Prof.dr.sc. Zdravka Leutar, socijalna radnica, e-mail:zleutar@pravo.hr
} 
Ljetopis socijalnog rada 2016., 23 (2), 253-274 str.

iznesene spoznaje i naglašavaju važnost ove tematike za kontekst socijalnog rada i pomažućih profesija.

\section{UVOD}

Proces deinstitucionalizacije je, uz podizanje svijesti o pravima osoba s intelektualnim teškoćama, rezultirao da one postaju sve prisutniji građani lokalnih zajednica. Procjenjuje se da ih je 34\% realiziralo samostalan život u zajednici, obilježen slabim socijalnim mrežama i isključivoj prepuštenosti formalnim sustavima podrške (Lindsay i sur., 2001.). Nova iskustva vezana uz život u zajednici donose i prava i obveza. Kršenjem društvenih pravila propisanih zakonima, poput počinjenog seksualnog nasilja, osobe s intelektualnim teškoćama dolaze u doticaj sa sustavom pravosuđa u kojem procesuiranje počinjenog kaznenog dijela može rezultirati različitim sankcijama (Lindsay i Taylor, 2008.). Sve veći broj istraživanja o i s počiniteljima seksualnog nasilja s intelektualnim teškoćama (u daljnjem tekstu koristit će se samo riječ počinitelji) (Lambrick, 2003.; Craig, 2010.) rezultat su mnogih društvenih promjena, od kojih su neke njihova veća prisutnost i uključenosti u život zajednice, priznavanje njihovih prava itd. Istraživanja se provode i zbog prepoznate važnosti prevencije, ali i pružanja podrške žrtvama, počiniteljima i osobama koje skrbe o njima (Rose i sur., 2002.). Intelektualne teškoće definiraju se poremećajem koji se javlja tijekom razvojnog perioda i uključuju ograničenja u intelektualnom i adaptivnom funkcioniranja u konceptualnim, socijalnim i praktičnim područjima, dok je kod osoba utvrđen kvocijent inteligencije u rasponu od 0 do 69 (American Psychiatric Association, 2013.; Uredba o metodologijama vještačenja, 2014., 2015.) što rezultira da su osobe s intelektualnim teškoćama izrazito heterogena skupina pojedinaca koja se dijeli na osobe s lakim, umjerenim, težim i teškim intelektualnim teškoćama.

\section{SEKSUALNOST OSOBA S INTELEKTUALNIM TEŠKOĆAMA KAO TEMELJ POČINJENJA SEKSUALNOG NASILJA}

Seksualnost i slika o sebi važne su odrednice života svake osobe. Seksualnost osoba s intelektualnim teškoćama poimana je perverznom i tabu temom (Isler i sur., 2009.; Lindsay, 2009.; Winges-Yanez, 2014.). Nerijetko ih se stigmatizira hiperseksualiziranim i seksualno devijantnim (Lunsky i sur., 2007.; Isler i sur., 2009.; Winges-Yanez, 2014.) što rezultira društvenom kontrolom njihove seksualnosti (Nezu, Fiore i Nezu, 2006.; Winges-Yanez, 2014.). Stigma seksualnih predatora rezultira

\section{4 članci}


roditeljskim strahom za djecu ukoliko u susjedstvu živi muškarac s intelektualnim teškoćama (Lindsay, 2004.; Nezu, Fiore i Nezu, 2006.; Winges-Yanez, 2014.) iako Lindsay (2009.) naglašava da su u većini slučajeva oni tihi, konzervativni, socijabilni i izrazito dobri susjedi koje se neopravdano stigmatizira opasnima.

Spolni razvoj muškaraca s intelektualnim teškoćama obilježen je drugačijim sposobnostima učenja, nametnutim ograničenjima, segregacijom, osporavanjem prava na privatnost, prekomjernim korištenjem medikamentoznih sredstava koja mogu utjecati na spolni nagon i izostankom znanja o seksualnosti (Lambrick, 2003.; Nezu, Greenberg i Nezu, 2006.; Lunsky i sur., 2007.). Vezano uz spolnost muškaraca s intelektualnim teškoćama, neki autori (Nezu, Fiore i Nezu, 2006.) naglašavaju da je kod velikog broja njih prisutno zatomljivanje emocija poput ljutnje, agresivnosti, zbunjenosti, žalosti i usamljenosti. Stoga se postavlja pitanje zbog čega stručnjaci, unatoč suvremenim spoznajama, i dalje osporavaju pravo na seksualnost osobama s intelektualnim teškoćama? Je li riječ o strahu, neznanju, društvenoj kontroli ili stavovima o osobama kao vječnoj djeci? Osporavanje zbog straha od neželjenih trudnoća i spolno prenosivih bolesti rezultira nemogućnošću da osoba u potpunosti razvije svoj identitet i ostvari seksualnu i emocionalnu vezu s drugom osobom. Time dolazi do razvoja frustracija, što u konačnici može rezultirati poremećajima ličnosti i činjenjem seksualnog nasilja. Needuciranost je jedan od razloga osporavanja prava na seksualnost, što uz negativne stavove rezultira nepoštovanjem individualnosti osoba s intelektualnim teškoćama. Budući da ih većina živi u okruženjima gdje im se ne odobrava spolni razvoj (kao i razvoj mnogih drugih potencijala), neodgovarajuća seksualna ponašanja trebaju se povezivati s razvojnim i okolinskim čimbenicima, a ne seksualnom devijantnošću osobe (Lindsay, 2009.). Slično smatraju i Michie i sur. (2006.) naglašavajući da se neprihvatljivo seksualno ponašanje muškaraca s intelektualnim teškoćama temelji na izostanku znanja o seksualnosti te nerazumijevanju i nemogućnosti postizanja onoga što se očekuje od osobe po pitanju seksualnosti. Istraživanje van Vugt i sur. (2011.) pokazuje da adolescenti s intelektualnim teškoćama imaju niži stupanj moralnog prosuđivanja u odnosu na adolescente bez intelektualnih teškoća, osobito u općim životnim situacijama, situacijama vezanim za seksualni čin i kada su oni žrtve.

\section{OBILJEŽJA LIČNOSTI POČINITELJA SEKSUALNOG NASILJA S INTELEKTUALNIM TEŠKOĆAMA}

Unatoč porastu broja istraživanja vezanih uz ovu tematiku, primjetno je da se samo nekolicina autora posvetila sustavnom proučavanju neprihvatljivog seksualnog ponašanja osoba s intelektualnim teškoćama. Budući da je sposobnost poči- 
njenja seksualnog nasilja povezana s funkcionalnim i kognitivnim sposobnostima osobe, počinitelji su u većini slučajeva muškarci s lakim intelektualnim teškoćama (Klimecki, Jenkinson i Wilson, 1994.; O' Connor, 1996.; Lambrick, 2003.; Cockram, 2005.a; Keeling, Beech i Rose, 2007.; Carson i sur., 2014.), dok oni s umjerenim intelektualnim teškoćama rijetko (Lindsay, 2002., 2009.). Pretpostavka o pet puta većoj vjerojatnosti da će muškarci s intelektualnim teškoćama počiniti seksualno nasilje u odnosu na muškarce bez intelektualnih teškoća (Lindsay, 2002.) utemeljena je na obilježjima ličnosti poput povećane impulzivnosti, ljutnje i agresivnosti, ne preuzimanju odgovornosti za vlastito ponašanje, nižoj toleranciji na frustraciju, teškoćama u apstrahiranju posljedica počinjenog djela, nerazumijevanju kaznene odgovornosti, problemima s percepcijom određenog odnosa te nemogućnosti samokontrole i seksualnog nagona (Rose i sur., 2002.; Browne i McManus, 2010.). Počinitelji nerijetko imaju konfuznu sliku o sebi, nestabilne odnose s vršnjacima, manjak znanja o seksualnim i društvenim odnosima, izostanak seksualnih i emocionalnih odnosa s drugima, negativna iskustva vezana za prvo seksualno iskustvo (npr. zlostavljanje), nerazvijene strategije suočavanja sa stresom i rješavanja problema te su kod njih prisutni izostanak socijalne prilagođenosti, empatije, socijalnih vještina i osobnih snaga, nisko samopouzdanje i nepoznavanje zakona (O' Connor, 1996.; Lindsay, 2002., 2009.; Courtney, Rose i Mason, 2006.; Nezu, Fiore i Nezu, 2006.; Keeling, Beech i Rose, 2007.; Salekin, Olley i Henge, 2010.).

Znaju biti uvjereni u postajanje ljubavne veze ukoliko poznaju žrtvu otprije (osoba je prema njima bila ljubazna ili kurtoazna) te prilikom čina nasilja ne uzimaju u obzir prisutnosti drugih osoba (Timms i Goreczny, 2002.). Često su nesigurni oko mjesta gdje se mogu upustiti u seksualni čin i imaju teškoće u prosuđivanju godina osobe koja ih seksualno privlači (Briggs i sur., 1996., prema Craig, 2010.). Počinit će seksualno nasilje na javnom mjestu zbog nedostatka znanja o seksualnosti i nerazumijevanja koncepta privatnosti, nemogućnosti kontroliranja seksualnih nagona i izostanka svijesti o pogrešnosti svog postupka, što dovodi do zaključka da je njihov napad oportunistički i impulzivan (Thompson i Brown, 1997.; Browne i McManus, 2010.). U istraživanju O' Connor (1996.) sudionici su u većini slučajeva priznali počinjeno nasilje, naveli da su svjesni neprihvatljivosti učinjenog te da razumiju što su tjelesne, ali ne i što su emocionalne i psihičke posljedice učinjenog seksualnog nasilja za žrtvu.

Nedostatak socijalnih vještina, poput pristupanja drugoj osobi, započinjanja razgovora, iskazivanja privlačnosti i simpatije itd. kod adolescenata s intelektualnim teškoćama može pridonijeti počinjenju seksualnog nasilja (Timms i Goreczny, 2002.). Navedene karakteristike počinitelja objedinjene su pod terminom counterfeit deviance koji pretpostavlja da će neki počiniti seksualno nasilje jer ne razumiju društvena pravila, zakone, etiku, moral, običaje i interpersonalne odnose, nisu svje-

\section{6 članci}


sni tabu tema koje se odnose na seksualnost, ne mogu realizirati seksualni odnos, posjeduju ograničene komunikacijske vještine, koriste drugačije komunikacijske obrasce itd. (Luiselli, 2000., prema Lindsay, 2002.; Michie i sur., 2006.; Griffiths, Fedoroff i Richards, 2010.). Faktori povezani s počinjenjem ovog nasilja su isto tako iskustvo institucionalizacije, nerazvijene vještine rješavanja problema, nezaposlenost te izostanak podrške izvan one formalne (O' Connor, 1996.). Za naglasiti je da je rizik za počinjenje seksualnog nasilja veći ukoliko su osobe odrasle u obiteljima u riziku i imaju iskustvo međugeneracijskog prijenosa seksualnog nasilja (Thompson i Brown, 1997.; Holland, Clare i Mukhopandhyay, 2002.; Lindsay i sur., 2001.; Lindsay, 2002., 2004.; Nezu, Fiore i Nezu, 2006.; Nezu, Greenberg i Nezu, 2006.; Browne i McManus, 2010.; Craig i Lindsay, 2010.; van der Put i sur., 2014.). Prema Lee i sur. (2002.), doživljeno tjelesno ili seksualno zlostavljanje i obiteljska nefunkcionalnost su faktori rizika za uobičajeni razvoj osobe, dok je emocionalno zlostavljanje faktor rizika za razvoj različitih parafilija. Povezano s doživljenim nasiljem, Nezu, Fiore i Nezu (2006.) navode da su neki od počinitelja kao način suočavanja s vlastitim iskustvima tjelesnog i seksualnog nasilja razvili uvjerenja da kada oni to isto čine drugima zapravo štite sebe.

Ranije navedeni manjak socijalnih vještina smatran je većim faktorom rizika za počinjenje seksualnog nasilja nego li devijantno ponašanje, doživljeno zlostavljanje/ zanemarivanje i intelektualno funkcioniranje osobe (Nezu, Greenberg i Nezu, 2006.). Uz intelektualno funkcioniranje, kao faktore rizika treba promatrati i duševne smetnje osobe, deficite u vještinama prilagodbe, ali i ekscesivna neprikladna ponašanja (Lindsay, 2004.; Hogue i sur., 2007.) poput verbalne i fizičke agresije (Taylor, 2002.; Camilleri i Quinsey, 2011.). Istraživanja (Cockram, 2005.a; Jones, 2007.; Steptoe i sur., 2008.; Camilleri i Quinsey, 2011.) ukazuju da obilježja počinitelja mogu biti kategorizirana u ona koja nisu povezana s intelektualnim teškoćama (npr. antisocijalni stavovi, poremećaj ličnosti, kriminalitet u obitelji, mlađa dob, problemi mentalnog zdravlja) i ona koja su izravno povezana s intelektualnim teškoćama (npr. teškoće razumijevanja, ponašajni problemi u djetinjstvu, nezaposlenost, niži socioekonomski status, devijantne seksualne želje, neasertivnost, nisko samopouzdanje) i koja utječu na recidivizam.

Istraživanje Courtney, Rose i Mason (2006.) pruža sljedeća saznanja: većini počinitelja su za odabir žrtve bili važni njezina dob i atraktivnost, navodili su da je žrtva sama pokrenula početak napada (povezanost s nerazumijevanjem interpersonalnih odnosa), iskazivali su malo empatije za žrtve, poricali učinjeno, isticali stres kao reakciju na uhićenje i sebe poimali žrtvom, iako ih je većina izjavila da su svjesni da su prekršili zakon. Ovim istraživanjem utvrđena su dva tipa počinitelja: groomer (duže vrijeme planira napad kroz planiranje seksualnog kontakta sa žrtvom) 
i grabber (ne planira i napada nepoznate žrtve što se često pojavljuje kao rezultat neuspjelog stupanja u kontakt sa žrtvom zbog nedostatka socijalnih vještina).

Nedostatak socijalnih vještina, zajedno s izostankom informacija i znanja, znaju biti temelj nerazumijevanja prihvatljivog seksualnog ponašanja. Stoga su upravo to područja na kojima stručnjaci trebaju intenzivnije raditi s mladima s intelektualnim teškoćama. Pružanjem informacija i edukacijom može se djelovati na stavove i uvjerenja osobe, čime se djelomično može i prevenirati seksualno nasilje. Ukoliko se navedena obilježja ličnosti povežu s ranije obrađenom seksualnošću, može se zaključiti kako upravo osporavanje prava i needuciranje o seksualnosti rezultiraju zatomljivanjem seksualnosti, što može rezultirati razvojem devijantnih seksualnih maštarija i počinjenjem seksualnog nasilja. Uz educiranje o seksualnosti, mladima s intelektualnim teškoćama potrebno je osigurati i razvoj socijalnih vještina, budući da istraživanja pokazuju da je manjak istih jedna od karakteristika počinitelja. Naravno, destigmatizacija seksualnosti kod ovih osoba neophodna je za cijelu zajednicu, ali i za same osobe, budući da stigmatizacija rezultira autostigmatizacijom. Međutim, većina autora naglašava iskustvo doživljenog nasilja kao snažni rizik za počinjenje seksualnog nasilja. Uz navedenu spoznaju nameće se pitanje koliko je osoba s intelektualnim teškoćama imalo priliku nakon iskustva nasilja u kojem su bili žrtve razgovarati sa stručnjacima i suočiti se s doživljenom traumom? Kolika je stopa prijavljenog i procesuiranog nasilja nad osobama s intelektualnim teškoćama? Ukoliko su osobama pružene pomoć i podrška, i dalje ostaju nedoumice vezane uz adekvatnost i kvalitetu istih. Stoga je potrebno naglasiti neophodnost adekvatnog tretmana sa žrtvama nasilja s intelektualnim teškoćama kako bi se barem nasilje preveniralo u segmentu u kojem ono generira novo nasilje, a žrtva postaje počinitelj nasilja.

\section{OBLICI I ŽRTVE SEKSUALNOG NASILJA}

Seksualno nasilje može se poimati kroz tri kategorije: bez kontakta (npr. nedolično izlaganje, pokazivanje pornografije, pornografsko fotografiranje, verbalno seksualno uznemiravanje), kontakt preko odjeće (npr. dodirivanje preko odjeće intimnih dijelova tijela) i s kontaktom (npr. masturbacija, seksualni čin) (Thompson,1997.). Navedene kategorije ili vrste seksualnog nasilja u Hrvatskoj su u pravnom smislu definirane Kaznenim zakonom koji definira kaznena djela protiv spolne slobode i kaznena djela spolnog zlostavljanja i iskorištavanja djeteta (Kazneni zakon, 2011., 2012., 2015.). Rezultati istraživanja s ovim počiniteljima ukazuju da je najprisutniji oblik seksualnog zlostavljanja nedolično izlaganje, verbalno seksualno uznemiravanje, dodirivanje intimnih dijelova tijela preko odjeće, pokušaj/

\section{8 članci}


stvarna penetracije i masturbacija u javnosti (O' Connor, 1996.; Thompson, 1997.; Rose i sur., 2002.).

U prvoj polovici 20. stoljeća u većini slučajeva su i počinitelj i žrtva bili osobe s intelektualnim teškoćama (Lindsay, 2002.), što se može objasniti činjenicom da se prijavljeno nasilje dogodilo u ustanovama za odgoj i obrazovanje te stalni smještaj osoba s intelektualnim teškoćama. Suvremena istraživanja i statistike o žrtvama seksualnog nasilja počinjenog od muškaraca s intelektualnim teškoćama nude različite zaključke: nema specifičnosti kod odabira žrtve vezane za dob i spol (Thompson i Brown, 1997.; Gilby i sur., 1989., prema Craig, 2010.), žrtve su najčešće osobe koje počinitelji poznaju (Timms i Goreczny, 2002.; van den Bergh i Hoekman, 2006.), njima nepoznate osobe (prisjetiti se ranije navedene impulzivnosti) (Day, 1994., prema Craig i Lindsay, 2010.), druge osobe s intelektualnim teškoćama, žensko osoblje i žene u općoj populaciji (Thompson, 1997.; Hogue i sur., 2006.). Međutim, prevalencija prijavljenog i procesuiranog seksualnog nasilja pokazuje da su najčešće žrtve bile vršnjaci s intelektualnim teškoćama i djeca (O'Connor, 1996.; Lindsay i sur., 2001.; Rose i sur., 2002.; McGrath, Livingston i Falk, 2007.; Craig i Lindsay, 2010.). Temeljem istraživanja obrazaca ponašanja 950 počinitelja seksualnog nasilja Blanchard i sur. (1999., prema Lindsay, 2009.) zaključuju da će nasilje nad mlađom djecom češće počiniti oni koji imaju niži stupanj intelektualnog funkcioniranja. Utvrđena je i veza između razine inteligencije počinitelja i dobi žrtve, čime je niža razina inteligencije povezana s većim interesom počinitelja prema mlađoj muškoj djeci (Craig i Lindsay, 2010.). Jedno od objašnjenja je da su oni još uvijek razvojno nerazvijeni kao i djeca, njihov psiho-seksualni razvoj nije potpun, odnosno završen pa kod njih nema razlike u seksualnoj privlačnosti prema odraslima/djeci i ženama/muškarcima (Verberne, 1990., prema Thompson i Brown, 1997.). Potrebno je istaknuti da su navedene spoznaje utemeljene samo na kaznenim djelima koja su procesuirana, a istraživanja provedena sa sudionicima koji su pristali sudjelovati u njima. Stoga se postavlja pitanje što je sa seksualnim nasiljem koje počinitelj počini u npr. svojoj obitelji ili ustanovi, a koje ostaje neprijavljeno? Zasigurno velik broj počinitelja ostaje neprijavljen i nesankcioniran jer žrtve nisu svjesne što im se dogodilo (djeca mlađe dobi), ali i zbog stavova drugih koji nerijetko zataškaju počinjeno nasilje zbog obilježja počinitelja, poput intelektualnih teškoća, pripisivanja nerazumijevanja osobi što je napravila itd.

Prijavljeno nasilje može rezultirati kaznenim procesom u kojem mogu nastupiti problemi vezani uz počinitelje. Zbog prepoznate vulnerabilnosti osoba s intelektualnim teškoćama, kroz Konvenciju o pravima osoba s invaliditetom se pristupa potencijalnim problemskim situacijama kroz članak 12. u kojem se naglašavaju priznavanje jednakosti pred zakonom i zaštitni mehanizmi i članak 13. kroz pristupe pravosuđu na način da će se promicati odgovarajuća obuka zaposlenika pra- 
vosuđa (Zakon o potvrđivanju Konvencije UN-a o pravima osoba s invaliditetom i Fakultativni protokol uz Konvenciju o pravima osoba s invaliditetom, 2007., 2008.). Upravo je propagirana jednakost diskutabilna jer se tijekom procesa ponekad ne uzimaju u obzir u dovoljnoj mjeri specifičnosti počinitelja temeljem utvrđenih intelektualnih teškoća koje su izuzetno važne. Propisani pristup pravosuđu kroz prilagodbe upitan je u svojoj provedivosti. Tijekom istražnih radnji diskutabilni su senzibiliziranost i vještine stručnjaka po pitanju rada s osumnjičenicima s intelektualnim teškoćama, budući da je veliku pažnju potrebno posvetiti obavijesnom razgovoru. Upitno je koliko su osumnjičenici svjesni da imaju pravo na dodatnu podršku za vrijeme istražnog procesa i kaznenog postupka. Za vrijeme davanja iskaza počiniteljima je izrazito teško shvatiti koncept upozorenja i prava kada im ih objašnjavaju policijski službenici, pratiti sudski postupak i shvatiti koje su njegove posljedice (Jones, 2007.; Salekin, Olley i Hedge, 2010.). Rezultati istraživanja o kaznenim postupcima u kojima sudjeluju počinitelji s lakim intelektualnim teškoćama pokazuju da su nekritični prilikom davanja iskaza i ne razumiju za što ih se sumnjiči (McGillivray $i$ Waterman, 2003.), iskazuju ograničeno razumijevanje ili nerazumijevanje procedure, uz čestu tendenciju lažnih priznanja djela tijekom obavijesnih razgovora (Clare i Gudjonsson, 1995., prema Barron, Hassiotis i Banes, 2004.), ne razumiju određene apstraktne koncepte poput prava, društvenih pravila i tabu tema (Lindsay, 2002.), dok Craig (2010.) navodi da pokazuju vrlo ograničeno znanje o zakonima. Stoga je mlade $s$ intelektualnim teškoćama potrebno educirati ne samo o seksualnosti, već i o neprimjerenom i zabranjenom seksualnom ponašanju i posljedicama istog. Osobe s lakim i umjerenim intelektualnim teškoćama mogu, imaju pravo i moraju biti upoznate s kaznenom odgovornošću i neprihvatljivosti seksualnog nasilja. Navedeno se može povezati s istraživanjima koja pokazuju da su većina počinitelja osobe s lakim intelektualnim teškoćama koje su ostvarile donekle samostalan život, zaposlene su na poslovima koji zahtijevaju ograničene kognitivne vještine i imaju skromne socijalne mreže (Steptoe i sur., 2006.; Salekin, Olley i Hedge, 2010.).

\section{TRETMANI S POČINITELJIMA SEKSUALNOG NASILJA S INTELEKTUALNIM TEŠKOĆAMA}

Procjenjuje se da od 2 do $30 \%$ zatvorske populacije čine osobe $s$ intelektualnim teškoćama (Hayes, 2005.; Lindsay i Taylor, 2008.; Lindsay, 2009.), s time da podaci o sankcioniranim počiniteljima seksualnog nasilja pokazuju da ih od 10 do 40\% ima intelektualne teškoće (Nezu, Nezu i Dudek, 1998.; Keeling, Beech i Rose, 2007.; Browne i McManus, 2010.). Potrebno je još jednom istaknuti da se u većini slučajeva radi o osobama s lakim intelektualnim teškoćama. Reyes i sur. (2006.)

\section{0 članci}


upozoravaju da je nezahvalno procjenjivati koliki postotak seksualnih prijestupnika ima intelektualne teškoće. Kod počinitelja je neophodno uz kazne provoditi i tretmane kako bi se osoba pokušala resocijalizirati u najvećoj mogućoj mjeri. Tijekom tretmana trebalo bi se u većoj mjeri uzimati u obzir intelektualne teškoće kao obilježje pojedinca, budući da određuju mnoge aspekte njegovog života.

Courtney, Rose i Mason (2006.) naglašavaju da nema modela intervencije i tretmana namijenjenih isključivo počiniteljima s intelektualnim teškoćama, već mnogi stručnjaci pogrešno pretpostavljaju da će tretmani za počinitelje bez intelektualnih teškoća biti djelotvorno i za njih. Nefokusirane i nespecifične intervencije u tretmanima često se temelje na pretpostavkama o teškoćama pružanja intervencija i terapija ovoj populaciji, malom broju takvih počinitelja, dvostrukim dijagnozama kod počinitelja i ranije navedenim stigmatizirajućim uvjerenjima o njihovoj seksualnosti (Timms i Goreczny, 2002.; Barron, Hassiotis i Banes, 2004.; Lambrick i Glaser, 2004.; Jones, 2007.). Počinitelje koji žive u zajednici usmjerava se u nespecijalizirane tretmane namijenjene osobama bez intelektualnih teškoća (Nezu, Fiore i Nezu, 2006.; Alexander i sur., 2010.; Keeling, Rose i Beech, 2008.; McKenzie i sur., 2012.) jer se njihovoj rehabilitaciji ne posvećuje pažnja (Cockram, 2005.b). Stoga je potrebno uvesti model rada s počiniteljima koji će biti utemeljen na njihovim iskustvima (Courtney, Rose i Mason, 2006.). Prije objašnjenja nekoliko postojećih tretmana koji su namijenjeni počiniteljima s intelektualnim teškoćama, potrebno je naglasiti da ponekad dostupna psihijatrijska skrb nije specijalizirana za osobe $s$ intelektualnim teškoćama, čime im se osporava pravo na mentalno zdravlje. Kao što navode Murphy i Sinclar (2009.), postoji svijest o neophodnosti specifičnih tretmana za ove počinitelje, ali nitko od stručnjaka nije raspoloživ za rad s njima.

Prije upućivanja u tretman bilo bi poželjno napraviti procjenu kompetencija i mogućnosti osobe da sudjeluju u postupku, individualnu procjenu za upućivanje na tretman, procjenu rizika za recidivizam i procjenu karakteristika počinitelja (Lindsay, 2002.), što se može povezati sa zaključkom Lambrick i Glasser (2004.) kako dio počinitelja ima izvrsne socijalne vještine, znanja o seksualnosti i planiraju napad perfidno. Na primjer, u Njemačkoj pravni sustav zahtijeva da se utvrdi na koji način je teški duševni poremećaj (od kojih su jedan intelektualne teškoće) utjecao na počinjenje seksualnog nasilja (Leue, Borchard i Hoyer, 2004.). Procjena je vrlo važan dio tretmana (Keeling, Beech i Rose, 2007.; Craig, 2010.; Embregts i sur., 2010.) budući da ima tri svrhe: procjenu rizika, potreba i načela razumijevanja (Keeling, Beech i Rose, 2007.). Procjena rizika sastoji se od prikupljanja podataka, bilježenja, interpretacije, komunikacije i implementacije plana za reduciranje rizika (Maden, 1996., prema Johnston, 2002.) te procjene spremnosti osobe na promjenu ponašanja. Stoga se kod ovih počinitelja vrši procjena razumijevanja kroz procjenu intelektualnog funkcioniranja (procjena kvocijenta inteligencije), adaptivnog funkcio- 
niranja (procjenjuju se vještine pojedinca koje se odnose na svakidašnje funkcioniranje, npr. socijalne vještine, komunikacija, vještine življenja, rješavanje problema i sl.) te procjenu pismenosti i razumijevanja (Keeling, Beech i Rose, 2007.). Kvalitetno i detaljno procjenjivanje ove tri razine omogućit će da se osoba uputi u tretman koji će imati najviše učinka za nju, koji će joj pomoći ispraviti negativne obrasce ponašanja i mišljenja, koji će joj omogućiti integraciju u društvo i sl. Sve to može dovesti do poboljšanja kvalitete života osobe i prevencije recidiva seksualnog nasilja. Kako bi se spriječio recidivizam, važno je da procjena bude što detaljnija i da se tretman bazira na onim područjima koja su rizična i koja dovode osobu u situaciju počinjenja seksualnog nasilja. Rad na promjenama kritičnih obrazaca ponašanja zahtijeva fleksibilan i dugotrajan pristup temeljen na multidisciplinarnom pristupu (Holland, Clare i Mukhopandhyay , 2002.), iako Lindsay i Smith (1998.) upozoravaju na nedostatak spoznaja o povezanosti izmjene stavova i obrasca ponašanja i dužine tretmana.

Tretmani namijenjeni počiniteljima s intelektualnim teškoćama dijele se na farmakološki, kognitivni, bihevioralni, individualni ili grupni, tretman socijalnih vještina, bio-psiho-socijalne intervencije, seksualnu edukaciju, programe u lokalnoj zajednici i sl. (Jones, 2007.). U prosjeku traju između 16 do 36 mjeseci (Keeling, Beech i Rose, 2007.).

U farmakološkom tretmanu, koji ima dugu povijest korištenja, intervencije se dijele na one s utjecajem na centralni živčani sustav smanjujući impulzivnost i regulirajući promjene ponašanja (Lambrick i Glaser, 2004.), čime se utječe na impulzivnost, agresiju i razne psihološke poremećaje poput npr. depresije (Lindsay, 2002.), te intervencije u kojima se lijekovima smanjuje razina testosterona što utječe na smanjenje seksualnog uzbuđenja osobe (Lambrick i Glaser, 2004.). Biološki tretman također u srž stavlja hormonalni i neurološki problem (Courtney, Rose i Mason, 2006.).

Kognitivni tretman i tehnike rješavanja problema temelje se na uvjerenju da je kod počinitelja potrebno promijeniti određena uvjerenja, postići uzročnost $s$ počinjenim djelom, povećati stupanj razumijevanja posljedica učinjenog na žrtvu (ponašajnih, kognitivnih, emocionalnih, razvojnih i socijalnih), identificirati i razumjeti nedostatke u vezi empatiranja sa žrtvom (izuzetno važan segment!) i povećati prosocijalno ponašanje sa svrhom razumijevanja žrtve (Nezu, Fiore i Nezu, 2006.; Lindsay, 2009.). Smatra se da tretman može utjecati na počiniteljeve stavove i uvjerenja, način razmišljanja i sl. (Lindsay, 2002.).

Svrha bihevioralnog tretmana je poboljšati bihevioralne kompetencije u svakodnevnim životnim vještinama, opće interpersonalne i edukacijske vještine te posebne bihevioralne vještine koje se odnose na seksualnost i ponašanje, budući da pretpostavlja uzročno-posljedičnu vezu između neprihvatljivog podražaja i

\section{2 članci}


odgovora na istog (Plaud i sur., 2000., prema Lindsay, 2002.; Courtney, Rose i Mason, 2006.; Nezu, Fiore i Nezu, 2006.; Nezu, Greenberg i Nezu, 2006.; Keeling, Rose i Beech, 2008.). Njime se utječe na promjenu ponašanja jer osoba usvaja i vježba nove, poželjne obrasce ponašanja i odbacuje stare, nepoželjne obrasce ponašanja koji ju dovode u počinjenje seksualnog nasilja.

Nezu, Greenberg i Nezu (2006.) kreirali su tretman usmjeren na rješavanje problema za ovu skupinu počinitelja seksualnog nasilja koji uključuje terapiju usmjerenu na rješavanje problema, kontroliranje stresa i bijesa, kognitivno restrukturiranje, trening interpersonalnih vještina, socijalnu i seksualnu edukaciju te funkcionalnu obiteljsku terapiju.

Grupni tretman prepoznat je izuzetno učinkovitim (Rose i sur., 2002.; Lambrick i Glasser, 2004.) jer se kroz njega svaka informacija koja se tiče ponašanja ili stavova koji mogu dovesti do kriminalnog ponašanja razrađuje u detalje kroz individualno procjenjivanje i razgovor u grupi te detaljno analiziranje i razrađivanje poricanja učinjenog, preuzimanje odgovornosti, usvajanja štetnosti i posljedica učinjenog (Lindsay i Smith, 1998.). Isto vrijedi i za počinitelje bez intelektualnih teškoća koji kroz tretman trebaju prihvatiti odgovornost za djela koja su učinili, naučiti što je empatija prema žrtvi i rasvijetliti koji su rizični faktori koji ih mogu dovesti do počinjenja novih kaznenih djela (Mužinić i Vukota, 2010.). Grupni tretman uključuje edukaciju o socijalnim vještinama i seksualnom ponašanju, rad na stavovima i percepciji, rad na snižavanju neprikladnih i podizanju prikladnih uzbuđenja, tretiranje seksualnih disfunkcija (O'Connor i Rose, 1998., prema Rose i sur., 2002.), definiranje vlastitih osjećaja i osjećaja drugih, rad na asertivnosti, prihvaćanje utjecaja kaznenog djela na žrtve, učenje procedura samokontrole i metoda izbjegavanja rizičnih situacija (Lindsay i Smith, 1998.). Neke od tehnika koje se koriste su igranje uloga, interaktivne vježbe, video i druge različite formalne tehnike učenja poput npr. rada u paru sa stručnjacima i sl. (Rose i sur., 2002.). Neke od prednosti grupnog tretmana u radu s počiniteljima seksualnog nasilja su grupna konfrontacija, međusobna podrška i ohrabrenje počinitelja da jedni drugima budu model u suočavanju s negiranjem ili umanjivanjem počinjenog (Association for the Treatment of Sexual Abusers, 2008.). Upravo je i ranije spomenuto istraživanje Courtney, Rose i Mason (2006.) pokazalo da je grupni tretman izrazito učinkovit jer je baziran na treningu socijalnih vještina i edukaciji o seksualnosti. Istraživanje Lunsky i sur. (2007.) s 48 mladih počinitelja pokazuje da seksualnu edukaciju dobiju tek kada počine seksualno nasilje. Na primjer, ovim tretmanom radi se na problematičnom ponašanju i kognitivnim promjenama, što uključuje poricanje da se kazneno djelo dogodilo, preuzimanje odgovornosti za djelo, poricanje namjere i podizanje svjesnosti o žrtvi (Lindsay i Smith, 1998.).

Analizom opisanih tretmana i intervencija primjetno je isticanje važnosti edukacije počinitelja na prihvaćanju normi zajednice te rad na empatiji i agresivnosti 
počinitelja. Uključenost u život zajednice tijekom tretmana može utjecati na smanjenje neprikladnog seksualnog ponašanja i recidivizam jer se počinitelji počinju identificirati s članovima zajednice i usvajaju pravila, norme, vrijednosti i običaje (Lindsay, 2004.). Usvojene bihevioralne i kognitivne vještine te strategije, poput komunikacije, trebale bi se moći vježbati s članovima zajednice (Lindsay, Michie i Lambrick, 2010.). Navedeno se može povezati sa socijalnom izolacijom koja je utvrđena faktorom rizika kod počinitelja, budući da se neki od počinitelja s vremenom osamljuju kako bi mogli provoditi vrijeme u seksualnim fantazijama devijantne prirode (Lindsay, 2009.). Izolacija od socijalnih odnosa nerijetko rezultira promijenjenim i distorziranim poimanjima odnosa i osoba, pa time i same seksualnosti. Vezano uz socijalne kompetencije, dobra procjena i tretman koji su fokusirani na povećanje socijalnih kompetencija i vještina mogu biti od velike koristi za počinitelje zbog prepoznatih deficita u socijalnim vještinama koji rezultiraju interpersonalnim problemima i razvojem neprimjerenih seksualnih ponašanja (Timms i Goreczny, 2002.). Zbog izostanka empatije i nerazumijevanja štetnosti seksualnog nasilja za žrtvu tijekom tretmana potrebno je raditi na postizanju većeg stupnja empatiranja, prepoznavanju emocija drugih, repliciranju emocija te donošenju odluka o odgovoru na emocije druge osobe (Ralfs i Beail, 2012.). Isto tako, terapeuti bi trebali imati specifična znanja i usmjeravati se na problem agresivnosti kod počinitelja (Carson i sur., 2014.).

Potrebno je naglasiti kako je i dalje prisutna nedovoljna posvećenost evaluaciji ovih tretmana, što je i jedan od razloga recidivizma (Lambrick, 2003.; Keeling, Rose i Beech, 2008.).

\section{RECIDIVIZAM}

Tijekom i po završetku tretmana često dolazi do recidivizma. Podaci pokazuju da je unutar prve godine, nakon odrađenog tretmana, $4 \%$ počinitelja počinilo recidivizam, a u sljedećih četiri godine njih $21 \%$ (Lindsay i sur., 2001.). Procjenjuje se da je stopa recidivizma kod osoba s intelektualnim teškoćama 6,8 puta veća nego kod osoba bez intelektualnih teškoća u roku dvije godine i 3,5 puta veća u roku od četiri godine (Craig i Hutchinson, 2005., prema Craig, 2010.). Naime, istraživanje Frize, Kenny i Lennings (2008.) pokazalo je da će mladi s intelektualnim teškoćama u većoj mjeri ponoviti kazneno djelo nego li oni bez intelektualnih teškoća. Istraživanja pokazuju da su počinitelji koji su bili u tretmanu manje od godine dana pokazali značajno manji napredak i veću vjerojatnost za počinjenje recidivizma nego oni koji su bili najmanje dvije godine u tretmanu (Lindsay i Smith, 1998.; Lindsay i sur., 2001.). Navedeno potvrđuju i rezultati istraživanja Klimecki, Jenkinson i Wilson (1994.) da je stopa recidivizma 30,8\% u prvih godinu dana. Prateći 121 počinitelja

\section{4 članci}


seksualnog nasilja s intelektualnim teškoćama u periodu od 13 godina, zaključilo se da na stope recidivizma počinitelja utječu nesmetani pristup zajednici i izostanak kontrole i nadzora od strane stručnjaka (Lindsay i sur., 2006.).

Podaci o povećanoj stopi recidivizma kod počinitelja koji su uključeni u tretman u lokalnoj zajednici (Andrews i Bonta, 2003., prema McGrath, Livingston i Falk, 2007.) mogu se objasniti dostupnošću potencijalnih žrtva. Međutim, potrebno se zapitati jesu li bili adekvatno uključeni u tretman, koliko je edukacija o seksualnosti, socijalnim vještinama i sl. bila provedena i njima razumljiva, je li se radilo na razrađivanju njihovog ponašanja, na osvještavanju o žrtvi, na edukaciji o kaznenoj odgovornosti i sl. te koliko su dugo bili u tretmanu, jesu li i koliko imali podršku te bili nadzirani od stručnjaka i sl. Potrebno je istaknuti da je unatoč podacima o recidivizmu od 10,7\%, utvrđeno da ih je 60\% bilo pod nadzorom 24 sata dnevno što im je vjerojatno ograničilo pristup potencijalnim žrtvama (McGrath, Livingston i Falk, 2007.; Craig i Lindsay, 2010.). Stoga se može zaključiti da nadzor nakon tretmana prevenira i smanjuje recidivizam.

Prediktori recidivizma seksualnog nasilja dijele se na statičke i dinamičke faktore rizika (Embregts i sur., 2010.) koji se mogu utvrđivati testovima i instrumentima. Statički faktori rizika koji mogu biti značajni za pojavu recidivizma su intelektualne teškoće, devijantna seksualna iskustva, antisocijalno ponašanje, impulzivnost, visoko seksualno uzbuđenje i seksualna preokupacija (Embregts i sur., 2010.), loš odnos s majkom, seksualno zlostavljanje u djetinjstvu i počinjenje seksualnog kaznenog djela koje uključuje nasilje (Lindsay i sur., 2002.). Ovi faktori korisni su za evaluaciju dugoročnih rizika (Craig, 2010.). Dinamički faktori rizika koji pridonose recidivizmu su prisutnost kognitivnih distorzija, slabe socijalne vještine, devijantne seksualne fantazije, zloupotreba opojnih sredstava, niska razina empatije, stavovi o počinjenom djelu itd. (Thornton, 2002., prema Keeling, Beech i Rose, 2007.; Craig, 2010.; Embregts i sur., 2010.). U svrhu prevencije recidivizma potrebno je počinitelju pružiti različite tehnike i strategije kako bi se prevenirale situacije u kojima može doći do seksualnog nasilja (Murphy i Sinclair, 2009.). Za kraj, nadovezujući se na određene aspekte tretmana koji mogu smanjiti recidivizam, utvrđeno je da ovi počinitelji mogu brzo usvojiti znanja o seksualnosti, ali im treba duže vremena kako bi postigli empatiranje sa žrtvom (Murphy i Sinclair, 2009.).

\section{ZAKLJUČNA RAZMATRANJA}

Sumirajući spoznaje temeljem iznesenih istraživanja o počiniteljima seksualnog nasilja s intelektualnim teškoćama, može se zaključiti da su počinitelji gotovo uvijek muškarci s lakim intelektualnim teškoćama čije su žrtve druge osobe s intelektualnim teškoćama i djeca. Obilježja ličnosti počinitelja, poput agresivnosti, 
kognitivnih deficita i izostanka empatije, uvijek je potrebno promatrati i dovoditi u vezu s odrednicama njihovih života, poput osporavanja i ograničavanja prava na seksualnost i intimnost, izostanka socijalnih vještina i znanja o seksualnosti, ali i doživljenim nasiljem koje je jedan od najvećih prediktora činjenja seksualnog nasilja. Istražne radnje i kazneni procesi nisu prilagođeni ovim počiniteljima, što rezultira izostankom specijaliziranih tretmana. Istraživanja ukazuju da je tretman s najvećim uspjehom onaj grupni, ali i da duži tretman i osigurani nadzor preveniraju činjenje seksualnog nasilja. Potrebno je naglasiti problem vezan uz izostanak evaluacije tretmana, što ukazuje da su počinitelji s intelektualnim teškoćama i dalje marginalizirana skupina korisnika u sustavu socijalne skrbi, zdravstva i pravosuđa.

Shodno navedenom, priznavanje prava na seksualnost i intimnost, socijalizacija, edukacija, omogućavanje prava na informacije, individualizirani pristup i specifična znanja neophodni su za prevenciju ove vrste nasilja. Budući da su muškarci s intelektualnim teškoćama u većini slučajeva od najranije dobi u sustavu socijalne skrbi, može se zaključiti da upravo socijalizacija u kojoj sudjeluju stručnjaci ima ključnu ulogu u prevenciji seksualnog nasilja. Osporavanje prava na seksualnost i nepružanje informacija o seksualnosti rezultiraju zatomljivanjem seksualnosti ili pak razvojem neprihvatljivih obrazaca seksualnog ponašanja s povećanim rizikom od počinjenja seksualnog nasilja. Stoga je uloga stručnjaka, osobito socijalnog radnika, upozoravati na i omogućiti ostvarivanje prava osoba s intelektualnim teškoćama na seksualnost te znanja i vještine o interpersonalnim i intimnim odnosima. Sustavna i pravovremena edukacija (od najranije dobi djeteta s intelektualnim teškoćama) treba pružiti znanja i vještine o društveno prihvatljivom ponašanju, moralnom prosuđivanju, empatiji, iskazivanju svojih emocija i želja, suzbijanju frustracije i agresije, iskazivanju i upravljanju vlastitom seksualnošću, upoznati osobe s kaznenopravnim sustavom kako bi usvojile znanje o neprihvatljivom ponašanju općenito (s naglaskom na seksualno neprihvatljivo ponašanje), odgovornosti za to ponašanje i kaznama. Grupni ili individualni tretman i edukacija trebali bi biti utemeljeni na specifičnostima vezanim za ovu populaciju s ciljem stvaranja socijalnih mreža podrške i potpore (osobito vezano uz nadzor počinitelja tijekom i nakon tretmana). Također, neophodan je individualizirani pristup u terapiji počinitelja seksualnog nasilja s intelektualnim teškoćama.

Zbog nepoznavanja kaznenopravnog sustava i neprijavljivanja nasilja jer čin ne prepoznaju nasilnim, ali i otežane mogućnosti artikuliranja što im se dogodilo, muškarci s intelektualnim teškoćama često postaju žrtve nasilja. Žrtve koje zbog prepuštenosti samima sebi doživljeno neprihvatljivo seksualno ponašanje mogu usvojiti prihvatljivim i počinju ga primjenjivati kao vlastito ponašanje prema drugima. Time nastaje začarani krug zlostavljanja. Prijavljujući sumnju u seksualno nasilje nad osobom s intelektualnim teškoćama, stručnjak ne samo da vrši svoju

\section{6 članci}


dužnost, već u jednoj mjeri prevenira da žrtva postane počinitelj nasilja. Time se sprječava odrastanje osoba s intelektualnim teškoćama u izolirane i stigmatizirane osobe neprihvatljivog seksualnog ponašanja. Stoga je neophodna edukacija svih stručnjaka pomažućih profesija o počiniteljima seksualnog nasilja s intelektualnim teškoćama, što je ujedno i svrha ovog rada.

LITERATURA

1. Association for the Treatment of Sexual Abusers. (2008). Sex offender treatment for adult males. Preuzeto s: https://www.atsa.com/sites/default/files/ ppSOAdultMaleTx.pdf (4.3.2016.).

2. Alexander, R. T., Green, F. N., O'Mahony, B., Gunaratna, I. J., Gangadharan, S. K. \& Hoare, S. (2010). Personality disorders in offenders with intellectual disability: A comparison of clinical, forensic and outcome variables and implications for service provision. Journal of Intellectual Disability Research, 54 (7), 650-658.

3. American Psychiatric Association (2013). Diagnostic and statistical manual of mental disorders (DSM-5). American Psychiatric Pub.

4. Barron, P., Hassiotis, A. \& Banes, J. (2002). Offenders with intellectual disability: The size oft he problem and therapeutic outcomes. Journal of Intellectual Disability Research, 46 (6), 454-463.

5. Barron, P., Hassiotis, A. \& Banes, J. (2004). Offenders with intellectual disability: A prospective comparative study. Journal of Intellectual Disability Research, 48 (1), 69-76.

6. Browne, K. D. \& McManus, M. (2010). Adolescents with intellectual disability and family sexual abuse. In: Craig, L. A., Lindsay, W. R. \& Browne, K. D. (eds.), Assessment and treatment of sexual offenders with intellectual disabilities: a handbook. UK: Wiley-Blackwell, 47-68.

7. Camilleri, J. A. \& Quinsey, V. L. (2011). Appraising the risk of sexual and violent recidivism among intellectually disabled offenders. Psychology, Crime \& Law, 17 (1), 59-74.

8. Carson, D., Lindsay, W. R., Holland, A. J., Taylor, J. L., O’Brien, G., Wheeler, J. R. \& Johnston, S. (2014). Sex offenders with intellectual disability referred to levels of community and secure provision: Comparison and prediction of pathway. Legal and Criminological Psychology, 19(2), 373-384.

9. Cockram, J. (2005a). Careers of offenders with an intellectual disability: The probabilities of rearrest. Journal of Intellectual Disability Research, 49 (7), 525-536.

10. Cockram, J. (2005b). Justice or differential treatment? Sentencing of offenders with an intellectual disability. Journal of Intellectual and Developmental Disability, 30 (1), 3-13. 
11. Courtney, J., Rose, J. \& Mason, O. (2006). The offence process of sex offenders with intellectual disabilities: A qualitative study. Sexual Abuse: A Journal of Research and Treatment, 18 (2), 169-191.

12. Craig, L. A. (2010). Controversies in assessing risk and deviancy in sex offenders with intellectual disabilities. Psychology, Crime \& Law, 16 (1-2), 75-101.

13. Craig, L. A. \& Lindsay, W. R. (2010). Sexual Offenders with intellectual disabilities: characteristics and prevalence. In: Craig, L. A., Lindsay, W. R. \& Browne, K. D. (eds.), Assessment and Treatment of Sexual Offenders with Intellectual Disabilities: a Handbook. London: Wiley-Blackwell, 13-35.

14. Embregts, P., van den Bogaard, K., Hendriks, L., Heestermans, M., Schuitemaker, M. \& van Wouve, H. (2010). Sexual risk assessment for people with intellectual disabilities. Research in Developmental Disabilities, 31 (3), 760-767.

15. Frize, M., Kenny, D. \& Lennings, C. (2008). The relationship between intellectual disability, Indigenous status and risk of reoffending in juvenile offenders on community orders. Journal of Intellectual Disability Research, 52 (6), 510-519.

16. Griffiths, D. M., Fedoroff, P. \& Richards, D. (2010). Sexual and gender identity disorders in people with intellectual disabilities. In: Craig, L. A., Lindsay, W. R. \& Browne, K. D. (eds.), Assessment and treatment of sexual offenders with intellectual disabilities: A handbook. London: Wiley-Blackwell, 111-135.

17. Hayes, S. (2005). Review of non-custodial interventions with offenders with intellectual disabilities. Current Issues in Criminal Justice, 17, 69-78.

18. Hogue, T., Steptoe, L., Taylor, J. L., Lindsay, W. R., Mooney, P., Pinkney, L., Johnson, S., Smith A. H. W. \& O'Brien, G. (2006). A comparison of offenders with intellectual disability across three levels of security. Criminal Behaviour and Mental Health, 16 (1), 13-28.

19. Hogue, T. E., Mooney, P., Morrissey, C., Steptoe, L., Johnston, S., Lindsay, W. R. \& Taylor, J. (2007). Emotional and behavioural problems in offenders with intellectual disability: Comparative data from three forensic services. Journal of Intellectual Disability Research, 51 (10), 778-785.

20. Holland, T., Clare, I. C. H. \& Mukhopandhyay, T. (2002). Prevalence of »criminal offending « by men and women with intellectual disability and the characteristics of »offenders«: Implications for research and service development. Journal of Intellectual Disability Research, 46 (1), 6-20.

21. Isler, A., Beytut, D., Tas, F. \& Conk, Z. (2009). A study on sexuality with the parents of adolescents with intellectual disability. Sexuality and Disability, 27 (4), 229-237.

22. Johnston, S. J. (2002). Risk assessment in offenders with intellectual disability: The evidence base. Journal of Intellectual Disability Research, 46 (1), 57-56.

23. Jones, J. (2007). Persons with intellectual disabilities in the criminal justice system: Review of issues. International Journal of Offender Therapy and Comparative Criminology, 1, 1-11. 
24. Kazneni zakon. Narodne novine, 25/2011., 144/2012., 56/2015., 61/2015.

25. Keeling, J. A., Beech, A. R. \& Rose, J. L. (2007). Assessment of intellectually disabled sexual offenders: The vurrent position. Aggression and Violent Behavior, 12 (2), 229-241.

26. Keeling, J. A., Rose, J. L. \& Beech, A. R. (2008). What do we know about the efficacy of group work for sexual offenders with an intellectual disability? Where to from here? Journal of Sexual Aggression, 14 (2), 135-144.

27. Klimecki, M. R., Jenkinson, J. \& Wilson, L. (1994). A study of recidivism among offenders with an intellectual disability. Journal of Intellectual and Developmental Disability, 19 (3), 209-219.

28. Lambrick, F. (2003). Issues surrounding the risk assessment of sexual offenders with an intellectual disability. Psychiatry, Psychology and Law, 10 (2), 353358.

29. Lambrick, F. \& Glaser, W. (2004). Sex offenders with an intellectual disability. Sexual Abuse: A Journal of Research and Treatment, 16 (4), 381-392.

30. Lee, J. K., Jackson, H. J., Pattison, P. \& Ward, T. (2002). Developmental risk factors for sexual offending. Child Abuse \& Neglect, 26 (1), 73-92.

31. Leue, A., Borchard, B. \& Hoyer, J. (2004). Mental disorders in a forensic sample of sexual offenders. European Psychiatry, 19 (3), 123-130.

32. Lindsay, W. R. \& Smith, A. H. (1998). Responses to treatment for sex offenders with intellectual disability: A comparison of men with 1-and 2-year probation sentences. Journal of Intellectual Disability Research, 42 (5), 346-353.

33. Lindsay, W. R., Law, J., Quinn, K., Smart, N. \& Smith, A. H. W. (2001). A comparison of physical and sexual abuse: Histories of sexual and non-sexual offenders with intellectual disability. Child Abuse \& Neglect, 25 (7), 989-995.

34. Lindsay, W. R. (2002). Research and literature on sex offenders with intellectual and developmental disabilities. Journal of Intellectual Disability Research, 46 (1), 74-85.

35. Lindsay, W. R., Smith, A. H. W., Law, J., Quinn, K., Anderson, A., Smith, A., Overend, T. \& Allan, R. (2002). A treatment service for sex offenders and abusers with intellectual disability: Characteristics of referrals and evaluation. Journal of Applied Research in Intellectual Disabilities, 15 (2), 166-174.

36. Lindsay, W. R. (2004). Sex offenders: Conceptualisation of the issues, services, treatment and management. In: Lindsay, W. R., Taylor, J. L., \& Sturmey, P. (eds.),Offenders with developmental disabilities. West Sussex: John Wiley \& Sons., 163-185.

37. Lindsay, W. R., Steele, L., Smith, A. H., Quinn, K., \& Allan, R. (2006). A community forensic intellectual disability service: Twelve year follow up of referrals, analysis of referral patterns and assessment of harm reduction. Legal and Criminological Psychology, 11 (1), 113-130. 
38. Lindsay, W. R. \& Taylor, J. L. (2008). Assessment and treatment of offenders with intellectual and developmental disabilities. In: Soothill, K., Rogers, P. \& Dolan, M. (eds.), Handbook of forensic mental health. Cullompton: Willan Publishing, 328-350.

39. Lindsay, W. R. (2009). The treatment of sex offenders with developmental disabilities: A practice workbook. West Sussex: John Wiley \& Sons.

40. Lindsay, W. R., Michie, A. M. \& Lambrick, F. (2010). Community-Based Treatment Programmes for Sex Offenders with Intellectual Disabilities. In: Craig, L. A., Lindsay, W. R. \& Browne, K. D. (eds.), Assessment and treatment of sexual offenders with intellectual disabilities: A handbook. London: Wiley-Blackwell, 271-292.

41. Lunsky, Y., Frijters, J., Griffiths, D. M., Watson, S. L. \& Williston, S. (2007). Sexual knowledge and attitudes of men with intellectual disability who sexually offend. Journal of Intellectual and Developmental Disability, 32 (2), 74-81.

42. McKenzie, K., Paxton, D., Michie, A., Murray, G., Murray, A. \& Curtis, J. (2012). Screening with young offenders with an intellectual disability. Journal of Forensic Psychiatry \& Psychology, 23 (5-6), 676-688.

43. McGillivray, J. A. \& Waterman, B. (2003). Knowledge and attitudes of lawyers regarding offenders with intellectual disability. Psychiatry, psychology and law, 10 (1), 244-253.

44. McGrath, R. J., Livingston, J. A. \& Falk, G. (2007). Community management of sex offenders with intellectual disabilities: Characteristics, services and outcome of a statewide program. Intellectual and Developmental Disabilities, 45 (6), 391-398.

45. Michie, A. M., Lindsay, W. R., Martin, V. \& Grieve, A. (2006). A Test of Counterfeit Deviance: A Comparison of Sexual Knowledge in Groups of Sex Offenders with Intellectual Disability and Controls. Sex Abuse, 18 (3), 271-278.

46. Murphy, G. \& Sinclair, N. (2009). Treatment for men with intellectual disabilities and sexually abusive behaviour. In: Beech, A. R., Craig, L. A. \& Browne, K. D. (eds.), Assessment and treatment of sex offenders: a handbook. Sussex: John Wiley \& Sons, 369-392.

47. Mužinić, L. \& Vukota, L. (2010). Seksualni delinkventi - Program prevencije recidiva. Hrvatski ljetopis za kazneno pravo i praksu, 17 (2), 619-623.

48. Nezu, C., Nezu, A. \& Dudek, J. (1998). A cognitive behavioral model assessment and treatment for intellectualy disabled sex offenders. Cognitive and Behavioral Practice, 5, 25-64.

49. Nezu, C. M., Fiore, A. A. \& Nezu, A. M. (2006). Problem solving treatment for intellectually disabled sex offenders. International Journal of Behavioral Consultation and Therapy, 2 (2), 266-276.

50. Nezu, C. M., Greenberg, J. \& Nezu, A. M. (2006). Project STOP: Cognitive behavioral assessment and treatment for sex offenders with intellectual disability. Journal of forensic psychology practice, 6 (3), 87-103. 
51. O'Connor, W. (1996). A problem-solving intervention for sex offenders with an intellectual disability. Journal of Intellectual and Developmental Disability, 21 (3), 219-235.

52. Ralfs, S. \& Beail, N. (2012). Assessing Components of Empathy in Sex-Offenders with Intellectual Disabilities. Journal of Applied Research in Intellectual Disabilities, 25 (1), 50-59.

53. Reyes, J. R., Vollmer, T. R., Sloman, K. N., Hall, A., Reed, R., Jansen, G., Carr, S., Jackson, K. \& Stoutimore, M. (2006). Assessment of deviant arousal in adult male sex offenders with developmental disabilities. Journal of applied behavior analysis, 39 (2), 173-188.

54. Rose, J., Jenkins, R., O'Connor, C., Jones, C. \& Felce, D. (2002). A group treatment for men with intellectual disabilities who sexually offend or abuse. Journal of Applied Research in Intellectual Disabilities, 15 (2), 138-150.

55. Salekin, K. L., Olley, J. G. \& Hedge, K. A. (2010). Offenders with intellectual disability: Characteristics, prevalence, and issues in forensic assessment. Journal of Mental Health Research in Intellectual Disabilities, 3 (2), 97-116.

56. Steptoe, L., Lindsay, W. R., Forrest, D. \& Power, M. (2006). Quality of life and relationships in sex offenders with intellectual disability. Journal of Intellectual and Developmental Disability, 31 (1), 13-19.

57. Steptoe, L. R., Lindsay, W. R., Murphy, L. \& Young, S. J. (2008). Construct validity, reliability and predictive validity of the dynamic risk assessment and management system (DRAMS) in offenders with intellectual disability. Legal and Criminological Psychology, 13 (2), 309-321.

58. Taylor, J. L. (2002). A review of the assessment and treatment of anger and aggression in offenders with intellectual disability. Journal of Intellectual Disability Research, 46 (1), 57-73.

59. Thompson, D. (1997). Profiling the sexually abusive behaviour of men with intellectual disabilities. Journal of Applied Research in Intellectual Disabilities, $10(2), 125-139$.

60. Thompson, D. \& Brown, H. (1997). Men with intellectual disabilities who sexually abuse: A review of the literature. Journal of Applied Research in Intellectual Disabilities, 10 (2), 140-158.

61. Timms, S. \& Goreczny, A. J. (2002). Adolescent sex offenders with mental retardation: Literature review and assessment considerations. Aggression and Violent Behavior, 7 (1), 1-19.

62. Uredba o metodologijama vještačenja (2014, 2015). Narodne novine, 153/2014., 108/2015.

63. van den Bergh, P. M. \& Hoekman, J. (2006). Sexual offences in police reports and court dossiers: A case-file study. Journal of Applied Research in Intellectual Disabilities, 19 (4), 374-382. 
64. van der Put, C. E., Asscher, J. J., Wissink, I. B. \& Stams, G. J. J. M. (2014). The relationship between maltreatment victimisation and sexual and violent offending: Differences between adolescent offenders with and without intellectual disability. Journal of Intellectual Disability Research, 58 (11), 979-991.

65. van Vugt, E., Asscher, J., Stams, G. J., Hendriks, J., Bijleveld, C. \& Van der Lan, P. (2011). Moral judgment of joung sex offenders with and without intellectual disabilities. Research in Developmental Disabilities, 32 (6), 2841-2846.

66. Winges-Yanez, N. (2014). Why all the talk about sex? An authoethnography identifying the troubling discourse of sexuality and intellectual disability. Sexuality and Disability, 32(1), 107-116.

67. Zakon o potvrđivanju Konvencije UN-a o pravima osoba s invaliditetom i Fakultativni protokol uz Konvenciju o pravima osoba s invaliditetom $(2007,2008)$. Narodne novine, Međunarodni ugovori, 6/2007., 5/2008. 
Marko Buljevac

Marija Luketić

Zdravka Leutar

University of Zagreb

Faculty of Law

Department of Social Work

\section{PERPETRATORS OF SEXUAL VIOLENCE WITH INTELLECTUAL DISABILITIES}

\section{ABSTRACT}

The aim of this paper is to present and problematize knowledge about sexual violence perpetrators with intellectual disabilities. These perpetrators are unrecognized and marginalized group of users, and because of that they do not receive appropriate treatment. This paper is divided in several thematic areas. At the beginning the sexuality of people with intellectual disabilities is problematized and it is associated with social status of this people and with their rights in the society. Personality characteristics are discussed together with their sexual rights and their right to gain information about interpersonal relationships. These findings are associated with knowledge and some earlier studies results about the forms of sexual violence committed by men with intellectual disabilities. Finally, the treatments for these perpetrators which are available in the countries of Western and Northern Europe and USA are explained and linked to the problems of recidivism. The authors' point out the most important findings about this theme in the last part of this paper, and discuss the importance of this theme for social workers and other experts working in helping professions.

Keywords: perpetrators of sexual violence with intellectual disabilities, sexuality of people with intellectual disabilities, personality characteristics of the perpetrator and the specifics of violence, treatment and recidivism. 
